\title{
Boomjuridischtijdschriften
}

\section{Onderstaand artikel is een voorpublicatie van hoofdstuk 10 van het Handboek Omgevingswet}

\author{
Aanbevolen citeerwijze bij dit artikel \\ , 'Onderstaand artikel is een voorpublicatie van hoofdstuk 10 van het \\ Handboek Omgevingswet', TO 2017-4, p. o-o
}

Auteurs gaan in hun artikel uit van de tekst van de Omgevingswet (Stb. 2016, 156) en van de tekst van de conceptversies van juni 2017 als zij verwijzen naar artikelen uit de Invoeringswet Omgevingswet en de algemene maatregelen van bestuur (www.omgevingswetportaal.nl).

Ten behoeve van de publicatie van het Handboek Omgevingswet zal het artikel - dan een hoofdstuk - worden geactualiseerd aan de hand van de Staatsblad-versies van de Invoeringswet Omgevingswet en de algemene maatregelen van bestuur. Tevens zal gebruik worden gemaakt - voor zover relevant voor het onderwerp - van de aanvullingswetten, het invoeringsbesluit en de ministeriële regeling.

10. De waterschapsverordening - mr. dr. H.J.M. Havekes en mr. W.J. Wensink

\subsection{Algemene introductie}

De waterschappen worden wel beschouwd als de oudste democratische bestuursvorm van Nederland. De eerste waterschappen stammen uit de dertiende eeuw. ${ }^{\mathbf{1}}$ Dit heeft alles te maken met de geografische ligging van Nederland. Meer dan de helft van ons land zou overstromen als er geen duinen en waterkeringen waren die bescherming bieden tegen stormvloeden van zee en hoog water van de rivieren. Ook extreme regenval kan lokaal tot grote wateroverlast leiden. De vele dijken, sluizen, gemalen, stuwen, kanalen en sloten houden Nederland bewoonbaar. Zonder deze waterstaatswerken zou meer dan de helft van ons land, waarbinnen ruim negen miljoen 
mensen wonen en werken, eenvoudigweg niet bestaan.

\subsubsection{Waterbeheer en waterschap}

Waterschappen zijn openbare lichamen met de waterstaatkundige verzorging van een bepaald gebied ten doel (art. 1 Wschw). Op regionaal en lokaal niveau zijn waterschappen verantwoordelijk voor het waterbeheer. Het begrip 'waterbeheer' kan daarbij worden omschreven als dat deel van de overheidszorg dat betrekking heeft op het keren van water, de waterhuishouding (oppervlaktewater en grondwater in zowel kwantitatieve als kwalitatieve zin) en de vaarwegen, en dat als zodanig gericht is op de bewoonbaarheid en de bruikbaarheid van de bodem en de bescherming en verbetering van het leefmilieu. Uit deze omschrijving blijkt tegelijkertijd dat de waterschappen met hun taakuitoefening invulling geven aan artikel 21 van de Grondwet: 'De zorg van de overheid is gericht op de bewoonbaarheid van het land en de bescherming en verbetering van het leefmilieu.' Door de voortgaande zeespiegelstijging, de klimaatverandering, de bodemdaling en de verstedelijking groeit het belang van een goede uitoefening van het waterbeheer. Een vijftal waterschappen is daarnaast belast met het wegenbeheer. Deze taak valt wel binnen het iets bredere begrip 'waterstaatszorg', maar behoort als zodanig niet tot het waterbeheer.

Het waterbeheer wordt uitgeoefend door middel van infrastructurele werken: de waterstaatswerken, zoals rivieren, meren, kanalen, grachten, sloten, dijken, gemalen, sluizen, stuwen, etc. Voor het bewoonbaar houden van ons land zijn deze waterstaatswerken van cruciale betekenis. De verordeningen van de waterschappen - onder de Omgevingswet waterschapsverordening geheten, maar van oudsher keur genoemd - spelen daarbij een doorslaggevende rol. Via deze verordeningen stellen de waterschappen kort gezegd de goede staat en werking van de waterstaatswerken veilig. Zo is het in algemene zin verboden om op, in, boven of onder waterstaatswerken zonder vergunning van het waterschap activiteiten te verrichten, zoals bouwen, graven en het aanbrengen van beplantingen.

De Waterschapswet geeft het juridisch kader voor de institutionele vormgeving van het waterschap. Met de inwerkingtreding van de Waterwet eind 2009 zijn de bepalingen over de taakuitoefening van het waterschap bijeengebracht. Op haar beurt wordt de Waterwet nagenoeg geheel in de Omgevingswet opgenomen. ${ }^{2}$ Daarmee vormt de Omgevingswet, naast de Waterschapswet, het juridisch kader voor het waterschap en zijn verordening.

Het waterbeheer vormt weliswaar een specifiek terrein van overheidszorg, maar heeft veel raakvlakken met andere beleidsterreinen, zoals de ruimtelijke ordening, het milieubeheer en 
het natuurbeheer. Een goede afstemming met deze beleidsterreinen is dan ook nodig. Men spreekt daarbij wel van 'integraal waterbeheer', waarin niet alleen rekening wordt gehouden met de relaties binnen het waterbeheer zelf (oppervlaktewater en grondwater, naar kwantiteit en kwaliteit), maar ook met de relaties met genoemde andere beleidsterreinen. Met de komst van de Omgevingswet worden deze beleidsterreinen samengebracht en vergaand geïntegreerd.

\subsubsection{Van keur naar waterschapsverordening}

Uitgangspunt van de Omgevingswet is dat decentrale overheden regels over de fysieke leefomgeving bijeenbrengen in één gebiedsdekkende regeling. ${ }^{3}$ Voor de gemeente is dat het omgevingsplan (zie hoofdstuk 8), voor de provincie de omgevingsverordening (zie hoofdstuk 9) en voor het waterschap de waterschapsverordening. In het waterbeheer speelt de waterschapsverordening (art. 2.5 Ow) een centrale rol. Het algemeen bestuur van het waterschap kan regels stellen over activiteiten die gevolgen hebben voor de fysieke leefomgeving (art. 4.1 Ow), bijvoorbeeld door het opnemen van een vergunningstelsel. De grondslag voor de waterschapsverordening blijft gelegen in artikel 56 jo. artikel 78 van de Waterschapswet. ${ }^{4}$ In zoverre wordt aangesloten bij de huidige situatie.

Het eerste lid van artikel 56 van de Waterschapswet bepaalt dat het waterschapsbestuur bevoegd is tot regeling en bestuur ter behartiging van de taken die het waterschap in het reglement zijn opgedragen. Dit betreft dus de autonome bevoegdheid van het waterschapsbestuur. Het tweede lid voegt hieraan toe dat regeling en bestuur van het waterschapsbestuur gevorderd kunnen worden bij wet, algemene maatregel van bestuur of bij provinciale verordening. Dit betreft medebewind door het waterschapsbestuur. De Omgevingswet verplicht, anders dan de Waterwet, het waterschap middels diverse bepalingen tot medebewind. ${ }^{\mathbf{5}}$ Zo bevat de Omgevingswet, zoals hierna nog aan de orde komt, in de hoofdstukken 2 en 4 bepalingen over de waterschapsverordening. Deze vormen een nadere uitwerking van artikel 78 van de Waterschapswet, dat bepaalt dat het algemeen bestuur de verordeningen maakt die het nodig oordeelt voor de behartiging van de taken die het waterschap zijn opgedragen.

Naast een verandering van naam - waterschapsverordening in plaats van keur - heeft de inwerkingtreding van de Omgevingswet nog de nodige consequenties voor de autonome verordening van het waterschap. Allereerst schrijft artikel 2.5 van de Omgevingswet voor dat een waterschap één verordening vaststelt voor alle regels die betrekking hebben op de fysieke leefomgeving. Dat heeft met name gevolgen voor de waterschappen die wegen in beheer hebben. De vijf waterschappen die het betreft zullen keur en wegenkeur moeten integreren in de waterschapsverordening. 
Daarnaast zijn er gevolgen voor de op grond van artikel 2.39 van de Omgevingswet vast te stellen legger. Een legger is een document dat normatief de fysieke kenmerken of toestand van waterstaatswerken omschrijft naar ligging, vorm, afmetingen en constructie. ${ }^{6}$ Er rust een leggerplicht op de waterschappen en het Rijk, maar niet op andere openbare lichamen die met het beheer van waterstaatswerken zijn belast. Een legger bevat geen normen waaraan derden rechten kunnen ontlenen, maar uitsluitend een concretisering van de gewenste fysieke kenmerken van het waterstaatswerk. Daarmee heeft de legger een wezenlijke functie bij de taakuitoefening door de waterbeheerder. Denk bijvoorbeeld aan het plegen van onderhoud aan waterstaatswerken. Kenbaarheid van de legger is ook voor burgers en bedrijven van belang. De legger is namelijk bepalend voor gedoogverplichtingen. Nieuw is dat de regels die gelden voor activiteiten ten aanzien van natte waterstaatswerken en de bijbehorende beperkingengebieden voortaan in de waterschapsverordening - en niet langer in de legger - worden opgenomen. De daadwerkelijke vaststelling van de beperkingengebieden met het bijbehorende regime van vergunningen en algemene regels gebeurt bij of krachtens de waterschapsverordening.

Ook ten aanzien van de inhoud van de waterschapsverordening wijzigt het nodige. De Omgevingswet gaat uit van het principe 'decentraal, tenzij'. ${ }^{7}$ Kortweg komt dit erop neer dat veel zaken niet meer landelijk maar in gemeentelijke omgevingsplannen en waterschapsverordeningen geregeld zullen worden. Sinds de inwerkingtreding van de Wet verontreiniging oppervlaktewateren (Wvo) in 1970 zijn er landelijke regels over het lozen op oppervlaktewater om verontreiniging tegen te gaan en te voorkomen. De Wvo is opgegaan in de Waterwet. ${ }^{\mathbf{8}}$ De kern van de regeling, waarmee verontreiniging moet worden voorkomen, staat in artikel 6.2, eerste lid, van de Waterwet, waarin het uitgangspunt is dat lozen ('brengen van stoffen') verboden is, tenzij er vergunning of vrijstelling is verleend. Met de inwerkingtreding van de Omgevingswet vindt zogezegd een omkering plaats. Lozingen zijn straks alleen verboden voor zover dat bij algemene maatregel van bestuur is bepaald (art. 5.1, tweede lid, onder c, Ow), of als dat is bepaald in een waterschapsverordening (art. 5.3 Ow). In het Besluit activiteiten leefomgeving (Bal) wordt er veel minder geregeld op rijksniveau ten aanzien van lozingen dan nu het geval is. Dat geldt zowel voor (indirecte) lozingen op de openbare riolering als voor (directe) lozingen op (regionaal) oppervlaktewater of een zuiveringtechnisch werk. Dat betekent meer ruimte voor decentrale regelgeving en mogelijkheden voor maatwerkregels naast of in afwijking van het Bal. Aangezien de gemeente veelal het bevoegd gezag is voor indirecte lozingen, zullen regels over indirecte lozingen op decentraal niveau een plek krijgen in het omgevingsplan. Decentrale regels over directe 
lozingen zijn straks terug te vinden in de waterschapsverordening. In beide gevallen is dit nieuw voor de betreffende decentrale overheden.

Voor niet-vergunningplichtige lozingen kunnen algemene regels gelden, die generieke regels geven voor activiteiten in de leefomgeving. Hiermee wordt voorkomen dat burgers en bedrijven steeds toestemming moeten vragen aan de overheid. Met de Omgevingswet wordt de tendens naar meer algemene regels, in plaats van vergunningen, voortgezet. In de afgelopen jaren is in het waterbeheer veelvuldig gebruik gemaakt van algemene regels, ook in de keuren van de waterschappen. Naar verwachting zal die beweging doorgaan en zullen de waterschapsverordeningen van de waterschappen nog meer algemene regels bevatten dan de huidige keuren.

Ten slotte is een belangrijke verandering dat in de waterschapsverordening regels over lozingen in relatie tot de waterkwaliteit komen. Wat betreft de waterkwantiteit nemen de waterschappen van oudsher al regels op in hun keuren. Zo is bij de meeste waterschappen een vergunning nodig voor het brengen of onttrekken van water in of uit oppervlaktewater boven een bepaalde hoeveelheid. Ook is het mogelijk dat er geen vergunningplicht geldt, maar dat er algemene regels gelden, met eventueel een meldplicht. In bijzondere situaties, zoals droogte of te veel water, kan er zelfs een absoluut verbod worden ingesteld op het brengen of onttrekken van water in of uit oppervlaktewater. In de Omgevingswet wordt uitgegaan van een zogenaamd integraal lozingenbegrip. Een lozingsactiviteit ziet op het brengen van stoffen, warmte en water (zie voor dit begrip de bijlage bij art. 1.1 Ow, onder A), en dus op waterkwaliteit (stoffen) en waterkwantiteit (water). Lozingsactiviteiten die in het Bal worden gereguleerd, hebben dus betrekking op waterkwaliteit én waterkwantiteit, met daarnaast mogelijk maatwerkregels in de waterschapsverordening. Zoals gezegd gaat de wetgever uit van het principe 'decentraal, tenzij', zodat de waterschapsverordeningen in de praktijk regels over zowel waterkwantiteit als waterkwaliteit zullen bevatten. Voor waterschappen is de regulering ten aanzien van de waterkwaliteit een nieuwe tak van sport. Het zal dus even wennen zijn, maar het biedt mogelijkheden voor regionaal maatwerk.

\subsection{Inhoud waterschapsverordening}

\subsubsection{Algemeen}

Voordat ingegaan wordt op de bepalingen van de Omgevingswet over de waterschapsverordening, dient voor een goed begrip daarvan de algemene opzet van de wet ten aanzien van decentrale bestuursorganen, waaronder het waterschap, te worden geschetst.

De gemeenten spelen een centrale rol bij het beheer en de 
ontwikkeling van de fysieke leefomgeving. Gemeenten zorgen voor de openbare ruimte, delen de schaarse ruimte toe aan maatschappelijke functies en zijn het bevoegd gezag voor het geven van toestemming voor veruit de meeste activiteiten van burgers en bedrijven in de fysieke leefomgeving. De waterschappen, organen van functioneel bestuur, zorgen voor het voor Nederland cruciale beheer van watersystemen. Een van de centrale uitgangspunten van de Omgevingswet is dat aangesloten wordt bij de bestaande bestuurlijke verantwoordelijkheden. In de memorie van toelichting 9 is dit uitgangspunt nadrukkelijk vastgelegd: 'Het wetsvoorstel brengt geen wijzigingen aan in het beginsel dat de taken voor de fysieke leefomgeving die de overheid moet behartigen in de eerste plaats bij gemeenten liggen en, waar het gaat om het waterbeheer, bij de waterschappen.' Het subsidiariteitsbeginsel, zoals dit ook is verwoord in de artikelen 115, tweede lid, van de Provinciewet, 117, tweede lid, van de Gemeentewet en 2, tweede lid, van de Waterschapswet, vormt dus een belangrijk principe van de Omgevingswet.

Een niet minder belangrijk uitgangspunt van de Omgevingswet vormt zoals gezegd het principe 'decentraal, tenzij'. ${ }^{10}$ Die voorkeur voor het decentrale niveau houdt onder meer verband met de notie dat decentrale overheden meer mogelijkheden hebben om bij de normstelling en uitvoering rekening te houden met gebiedseigen relevante feiten en omstandigheden. Daarmee hebben ze - dit geldt met name voor gemeenten, aangezien het waterschap een functionele taakstelling heeft - vaak ook meer mogelijkheden tot het maken van integrale afwegingen. Dit sluit bovendien aan bij het Europees Handvest inzake lokale autonomie van de Raad van Europa. Het Rijk en de provincies respecteren dit door uit te gaan van het subsidiariteitsbeginsel 'decentraal, tenzij' (zie in dit verband ook art. $2.3 \mathrm{Ow})$.

In dit kader is met name de passage in de memorie van toelichting over waterbeheer van betekenis:

'Het waterbeheer vormt een belangrijk onderdeel van de overheidszorg die gericht is op de bewoonbaarheid van ons land en de bescherming en verbetering van het leefmilieu. Deze achterliggende zorgplicht van de overheid is, zoals genoemd, vastgelegd in artikel 21 van de Grondwet. De doelstellingen van het waterbeheer vormen een uitwerking van deze grondwettelijke opdracht aan de overheid. Deze doelstellingen zijn:

- het voorkomen en waar nodig beperken van overstromingen, wateroverlast en waterschaarste, in samenhang met

- de bescherming en verbetering van de chemische en 
ecologische kwaliteit van watersystemen, en

- de vervulling van de op grond van de Omgevingswet aan watersystemen toegekende maatschappelijke functies.

Het regionale waterbeheer is in Nederland belegd bij de waterschappen, organisaties van functioneel bestuur. De waterschappen beheren ook een groot deel van de primaire waterkeringen. Waterschappen beschikken over een eigen belastinggebied om hun taken te bekostigen en over eigen bevoegdheden op het terrein van vergunningverlening en handhaving. Zij voeren hun taken uit binnen de kaders, zoals die door de algemene democratie worden opgesteld en vertalen deze in uitvoeringsgericht beleid en beheermaatregelen. ${ }^{\mathbf{1 1}}$

'Uit het oogpunt van subsidiariteit zijn', zo vervolgt de memorie van toelichting, 'de gemeenten en - waar het waterbeheer betreft - de waterschappen de bestuurlijke hoofdrolspelers in het omgevingsrecht.' Toch spelen ook het Rijk en de provincies een belangrijke rol in de zorg voor de fysieke leefomgeving. In de loop van de geschiedenis zijn delen van de zorg voor de fysieke leefomgeving bij het Rijk of de provincies belegd, omdat - in de formulering van de huidige Gemeentewet - 'het onderwerp van zorg niet op doelmatige en doeltreffende wijze door de gemeentebesturen kan worden behartigd'. Ook nu nog kunnen provinciebesturen of het Rijk besluiten om de zorg voor aspecten van de fysieke leefomgeving naar zich toe te trekken of voorwaarden te stellen aan de taak- of bevoegdheidsuitoefening door gemeenten of provincies.

In het huidige omgevingsrecht vinden we in ieder geval vijf typen gevallen waarin de zorg voor de fysieke leefomgeving wordt belegd bij het Rijk of de provincies:

- schaalniveau (fysieke onderdelen), waarbij onder meer gewezen wordt op de verantwoordelijkheid van het Rijk voor de rijkswateren en de hoofdinfrastructuur;

- schaalniveau (beleidsmatige onderdelen), waarbij op het behoud van werelderfgoed en het beleid rond de vestiging van kantoren, gezien de grootschalige leegstand, wordt gewezen;

- gelijk speelveld of beschermingsniveau, waarbij de bouwregelgeving en de milieuregelgeving worden genoemd;

- complexe initiatieven, zo zijn er initiatieven van bedrijven en uitvoerende overheden die omwille van hun schaalgrootte, maatschappelijk belang, gevolgen voor de fysieke leefomgeving of bestuurlijke complexiteit tot de zorg van het 
Rijk of de provincie worden gerekend;

- nationale veiligheid, zo gelden er bijvoorbeeld voor militaire activiteiten bijzondere vereisten voor de vertrouwelijkheid van de voorbereiding van een besluit. Het is niet doelmatig om in elke gemeente waar zich dergelijke activiteiten voordoen te voorzien in de vereiste technische en organisatorische randvoorwaarden hiervoor. Daarom is bijvoorbeeld in het huidige Besluit omgevingsrecht geregeld dat de vergunningen voor dergelijke activiteiten centraal worden verleend. ${ }^{\mathbf{2}}$

In de Omgevingswet is dit als volgt uitgewerkt. De beleidstaak voor water als onderdeel van de zorg voor de fysieke leefomgeving wordt, in lijn met de Waterwet, toegekend aan het Rijk voor de rijkswateren en aan de provincie voor de niet-rijkswateren. De beheertaak voor de rijkswateren is opgedragen aan Rijkswaterstaat als onderdeel van het ministerie van Infrastructuur en Milieu (IenM). Voor zover de provincie de beheertaak niet aan zich houdt, worden de waterschappen en gemeenten belast met de operationele waterbeheertaak binnen de beleidskaders die daarvoor worden gesteld. De waterschappen zijn in beginsel verantwoordelijk voor de totale afwatering in het stedelijk en landelijk gebied, de waterkwantiteit en de waterkwaliteit, inclusief de afvalwaterzuivering en het beheer van de waterkeringen. Tot de beheertaak van de gemeente behoren in het algemeen de aanleg en het onderhoud van de riolering en het beheer van de grondwaterstand in stedelijke gebieden. Op de wijze waarop de beheertaken worden vervuld, houden de provincies en de minister van IenM bestuurlijk toezicht. ${ }^{\mathbf{1 3}}$

Terzijde wordt erop gewezen dat de formulering van deze passage wat ongelukkig is. De clausulering 'Voor zover de provincie de beheertaak niet aan zich houdt' lijkt namelijk te suggereren dat de provincie min of meer vrij is om de operationele beheertaken op het terrein aan zich te houden. Niets is echter minder waar. Zo is de provincie op grond van het decentralisatiebeginsel van artikel 2, tweede lid, van de Waterschapswet, die op dit punt als organieke wet boven de Omgevingswet gaat, de facto verplicht om het watersysteembeheer en het zuiveringsbeheer aan waterschappen toe te delen. Slechts wanneer dit niet verenigbaar zou zijn met het belang van een goede organisatie van de waterstaatkundige verzorging kan van dit basisprincipe worden afgeweken. In de huidige waterschapsorganisatie is een dergelijke situatie niet goed denkbaar. Ten aanzien van de gemeenten bezit de provincie zelfs in het geheel geen afwegingsmogelijkheid. De wet thans de Waterwet en de Wet milieubeheer, straks de Omgevingswet deelt de operationele watertaken rechtstreeks aan de gemeenten toe.

In deze passages uit de memorie van toelichting komt nadrukkelijk tot 
uitdrukking dat de wetgever de bestaande taken en bevoegdheden van de waterschappen intact heeft willen laten. In wezen is dit ook de kern van het afsprakenkader dat de minister van IenM met de Unie van Waterschappen medio 2013 over de stelselherziening van het omgevingsrecht heeft afgesloten. ${ }^{\mathbf{1 4}}$ In dit afsprakenkader is overeengekomen dat 'de waterbeheerder bevoegd blijft voor de vergunningverlening en handhaving voor de handelingen in het watersysteem zoals nu geregeld onder de Waterwet en de keur (reikwijdte: veiligheid, kwantiteit en kwaliteit)'. Ook onder de Omgevingswet blijft het waterschap dus bevoegd gezag voor activiteiten in het regionale watersysteem en voor het vaststellen van een keur, zij het dat deze nu 'waterschapsverordening' heet. Dit doet niet alleen recht aan het uitgangspunt om aan te sluiten bij de bestaande bestuurlijke bevoegdheidsverdeling en het decentralisatiebeginsel, maar ook aan de historisch gegroeide situatie waarin waterschappen al vele eeuwen, en ver voordat er sprake was van een staat Nederland, keuren vaststellen. Die keuren vormen daarmee een van de oudste geschreven bronnen van ons rechtsstelsel. ${ }^{15}$ Dat die keuren soms ingrijpende bevoegdheden voor het waterschapsbestuur en robuuste verplichtingen voor de 'ingelanden' bevatten, onderstreept het cruciale karakter van een goed waterbeheer voor ons laaggelegen deltaland.

\subsubsection{Kernbepaling artikel 2.5 Omgevingswet}

Decentrale regelgeving vormt een van de (zes) kerninstrumenten van de Omgevingswet. Uitgangspunt is dat decentrale overheden de regels over de fysieke leefomgeving bijeenbrengen in één gebiedsdekkende regeling. ${ }^{\mathbf{1 6}}$ Dat bevordert de inzichtelijkheid, samenhang en naleving van de regelgeving. Voor de gemeente is dit het omgevingsplan, voor het waterschap de waterschapsverordening en voor de provincie de omgevingsverordening. Het algemeen bestuur van een waterschap kan op grond van artikel 4.1 van de Omgevingswet regels stellen over activiteiten die gevolgen hebben voor de fysieke leefomgeving en dit vindt plaats in de waterschapsverordening. Artikel 2.5 van de Omgevingswet bepaalt kort en krachtig dat het algemeen bestuur van het waterschap één waterschapsverordening vaststelt waarin regels over de fysieke leefomgeving worden opgenomen. De verordening is verplicht, het waterschapsbestuur moet deze vaststellen. De wettelijke basis voor deze verordening is dus artikel 2.5 van de Omgevingswet. Als aangegeven zijn ook de artikelen 56 en 78 van de Waterschapswet hier van belang, omdat deze bepalingen het algemene staatsrechtelijke kader voor het optreden van het waterschap in medebewind respectievelijk autonomie bevatten. ${ }^{17}$

De memorie van toelichting bij de Omgevingswet is betrekkelijk summier over deze nieuwe verordening van het waterschap. ${ }^{\mathbf{1 8}}$ Daarin wordt niet veel meer gezegd dan dat de waterschapsverordening gelijk 
te stellen is met de bestaande waterschapskeur, waarin vooral burgerbindende algemene regels en vergunningstelsels zijn opgenomen. Waar in de praktijk van de waterschappen nog andere beheerverordeningen gelden, bijvoorbeeld voor het wegbeheer, wordt in artikel 11.55 van de Invoeringswet Omgevingswet bepaald binnen welke termijn deze verordeningen moeten worden samengevoegd tot één waterschapsverordening. Het peilbesluit en de legger, waarvan de grondslag in afdeling 2.6 van de Omgevingswet is opgenomen, hoeven niet in de waterschapsverordening te worden opgenomen. Aangezien het van belang wordt geacht dat alle burgerbindende regels van het waterschap bijeen worden gebracht, moet de aanwijzing van beperkingengebieden (de bestaande 'beschermingszones') daarentegen wel in de waterschapsverordening en niet in de legger haar plaats hebben. Ook voor de opzet en inhoud van de legger heeft de Omgevingswet dus nadrukkelijk consequenties.

Dit neemt niet weg dat de verplichting om één gebiedsdekkende waterschapsverordening vast te stellen voor de waterschappen materieel niet heel grote consequenties lijkt te hebben. Zoals gezegd zullen daarin de huidige beschermingszones moeten worden opgenomen. Dat geldt ook voor de thans vaak nog afzonderlijk vastgestelde algemene regels voor uiteenlopende activiteiten. ${ }^{19}$ Voorts zullen de vijf wegbeherende waterschappen hun wegenkeur daarin moeten integreren en zullen die waterschappen die nog werken met een zogenaamde aansluitverordening, die de aansluiting van de gemeentelijke riolering op de zuiveringtechnische werken van het waterschap regelt, deze moeten integreren. Maar daarmee is de lijst zo ongeveer wel compleet. De inspraakverordening (art. $79 \mathrm{Wschw}$ ), die niet specifiek op de fysieke leefomgeving ziet, en de fiscale heffings- en kostentoedelingsverordeningen van de Waterschapswet en de Waterwet hoeven niet te worden geïntegreerd. ${ }^{\mathbf{2 0}}$ Voor de waterschappen lijken de consequenties dus te overzien. Dat hangt nog wel af van de inhoud van de algemene maatregelen van bestuur (art. 2.24 jo. art. 2.25 Ow) en de provinciale verordeningen (art. 2.23 Ow). Hierin kunnen namelijk instructieregels worden opgenomen voor de waterschapsverordening. Zo bepaalt artikel 6.1 van het Besluit kwaliteit leefomgeving (Bkl) dat het waterschap bij het stellen van regels over lozingsactiviteiten in zijn waterschapsverordening de eisen van de kaderrichtlijn water in acht neemt. Voor mogelijke provinciale instructies zullen de omgevingsverordeningen moeten worden afgewacht.

\subsubsection{Inhoud waterschapsverordening}

Wat de inhoud van de waterschapsverordening betreft is het goed om eerst te zien wat de inhoud van de bestaande waterschapskeuren is. Dan komen eventuele verschillen tussen het oude en het nieuwe regime immers het scherpst in beeld. In 2013 is door de Unie van 
Waterschappen ten behoeve van haar leden een zogenaamd keurkwartet ${ }^{\mathbf{2 1}}$ uitgebracht, dat achtereenvolgens bestaat uit:

- een model-Keur met toelichting;

- een model Algemene regels voor grondwater, keringen en kwantiteit;

- een model Beleidsregels voor grondwater, ecologie, keringen en kwantiteit;

- richtlijnen voor leggers oppervlaktewateren en keringen.

Als we ons hierbij concentreren op de inhoud van de model-Keur, dan is die keur kort samengevat als volgt opgebouwd. In hoofdstuk 1 is een aantal begripsbepalingen opgenomen en wordt aangegeven tot wie de verplichtingen van de keur zich richten. Hoofdstuk 2 gaat over beheer en onderhoud van waterstaatswerken en bevat een aantal onderhoudsverplichtingen, waarbij voor de aanwijzing van onderhoudsplichtigen wordt verwezen naar de legger ingevolge (art. 78, tweede lid, van) de Waterschapswet. ${ }^{22}$ Voor de situatie dat een actuele legger ontbreekt, is een bepaling over de onderhoudsplichtigen opgenomen. Hoofdstuk 3 betreft handelingen in watersystemen en bevat een aantal verbodsbepalingen behoudens vergunning van het waterschapsbestuur. Vergunningplichtige activiteiten zijn met name het in de nabijheid van waterstaatswerken of bijbehorende beschermingszones handelingen verrichten, werken behouden of voorwerpen laten staan of liggen alsmede het onttrekken van oppervlaktewater en grondwater. Hierbij wordt aangetekend dat de model-Keur conform de Waterwet, maar anders dan de Omgevingswet, uitgaat van het principe dat in beginsel (veel) activiteiten of handelingen verboden zijn, tenzij vergunning is verleend ('alles is verboden, tenzij'). Voorts bevat dit hoofdstuk de mogelijkheid van een algeheel verbod in geval van calamiteiten, een algemene zorgplicht voor eenieder, de basis voor algemene regels van het waterschapsbestuur, een meldplicht alsmede de vrijstelling van de vergunningplicht en de plicht tot het opstellen van een projectplan voor het waterschap voor projecten van ondergeschikt belang. Hoofdstuk 4 betreft toezicht en handhaving en bevat bepalingen over de aanwijzing van toezichthouders en de schouw (de doorgaans jaarlijkse inspectie door het waterschap of aan de regels wordt voldaan). Ook is in dit hoofdstuk een algemene strafbepaling voor overtreding van de keur opgenomen. Hoofdstuk 5 bevat ten slotte enkele overgangs- en slotbepalingen.

Het is voorts nuttig om kort stil te staan bij het model Algemene regels, dat deel uitmaakt van het keurkwartet, te meer waar de Omgevingswet het werken met algemene regels nadrukkelijk laat 
prevaleren boven het werken met vergunningplichten. Het model van de Unie van Waterschappen kent algemene regels voor waterkeringen, waterkwantiteit en grondwater. De methodiek is steeds gelijk, hetgeen het gebruiksgemak versterkt. Allereerst wordt voor een aantal aangegeven activiteiten vrijstelling verleend van de betreffende verbodsbepaling in de model-Keur. Vervolgens wordt een aantal voorschriften gesteld voor de betreffende activiteit, waaronder de verplichting deze tijdig aan het waterschapsbestuur te melden. Ten slotte wordt voorzien in overgangsrecht, dat onder meer inhoudt dat indien voor de activiteit reeds eerder een watervergunning is verleend, de vergunningvoorschriften als maatwerkvoorschriften als bedoeld in de keur worden beschouwd. De regels met betrekking tot waterkeringen zien op activiteiten zoals het aanbrengen van beplantingen, het bemesten en beweiden, het leggen van kabels en leidingen, het plaatsen van seizoensgebonden bebouwing op het strand en het plaatsen van kleine bouwwerken op waterkeringen en in de beschermingszone daarvan. De regels met betrekking tot waterkwantiteit zien op activiteiten zoals het aanleggen van steigers, bruggen, dammen, duikers en beschoeiing, drainage, het onttrekken van oppervlaktewater, het leggen van kabels en leidingen en het dempen en graven van wateren. De regels met betrekking tot grondwater zien op het onttrekken van grondwater, waarbij een aantal verschillende categorieën onttrekkingen onderscheiden wordt (bronbemalingen, proefbronneringen, bodemsaneringen, agrarische en overige onttrekkingen), en het infiltreren van hemelwater. Dit zijn de kleinere grondwateronttrekkingen. Net zoals onder de Waterwet (zie art. 6.4) is de provincie onder de Omgevingswet bevoegd gezag voor de grotere grondwateronttrekkingen (zie art. 5.9 Ow jo. art. 3.2 Omgevingsbesluit). In het kader van de totstandkoming van de Waterwet is wel overwogen om de grondwatertaak volledig aan de waterschappen op te dragen, maar onder meer vanwege de kennis bij de provincies, die al onder de vroegere Grondwaterwet bevoegd gezag waren, is hiervan afgezien.

De Omgevingswet bevat zelf relatief weinig bepalingen over de verplichte waterschapsverordening. Naast artikel 2.5, dat die verplichting in het leven roept, bepaalt artikel 4.1 in algemene zin dat in onder meer de waterschapsverordening met het oog op de doelen van de wet regels kunnen worden gesteld over activiteiten die gevolgen hebben of kunnen hebben voor de fysieke leefomgeving. Wat de waterschappen betreft lijkt die fysieke leefomgeving op het eerste oog beperkt tot het beheer van watersystemen, ${ }^{\mathbf{2 3}}$ maar dat lijkt een iets te krappe jas. Waar nodig zullen ook de zuiveringtechnische werken via de waterschapsverordening moeten kunnen worden beschermd. Artikel 4.22 jo. artikel 4.3 van de Omgevingswet voorziet weliswaar in rijksregels op dit punt, waarbij de doelmatige werking van zuiveringtechnische werken een van de achterliggende doelen is, maar vanuit de sterke decentralisatiegedachte van de Omgevingswet is het 
niet onlogisch dat ook het waterschapsbestuur zélf op dit vlak regels kan stellen, daar zit tenslotte ook de inhoudelijke technische kennis. Dit geldt temeer daar de memorie van toelichting zelf bepaalt dat, gelet op artikel 2.3, derde lid, van de Omgevingswet, in beginsel geen rijksregels gesteld worden met betrekking tot waterstaatswerken die niet in beheer bij het Rijk zijn. Die regels worden door waterschappen gesteld in de waterschapsverordening. ${ }^{\mathbf{2 4}}$ Overigens moet de beperking tot het beheer van watersystemen niet letterlijk worden genomen. Zo mag het waterschap in zekere zin 'het land op kruipen' en bijvoorbeeld ter voorkoming van wateroverlast eisen stellen aan het percentage verhard oppervlak in nieuwe bouwplannen, of compenserende waterberging eisen.

Voorts bevatten de artikelen 4.4 tot en met 4.7 van de Omgevingswet nog enkele bepalingen over het kunnen eisen van een aan de te verrichten activiteit voorafgaande melding, het kunnen instellen van een vergunningplicht, het kunnen stellen van maatwerkregels en voorschriften en het toestemming kunnen verlenen voor 'gelijkwaardige' maatregelen. Bij het stellen van maatwerkregels en voorschriften kan, als dat in de regels van het Rijk of de provinciale omgevingsverordening is bepaald, op grond van de artikelen 4.5 en 4.6 van de Omgevingswet worden afgeweken van die hogere regelingen. Artikel 4.8 van de Omgevingswet geeft vervolgens aan wie het bevoegd gezag is voor de melding, het maatwerkvoorschrift en de toestemming tot het treffen van een gelijkwaardige maatregel. Artikel 16.2 van de Omgevingswet merkt ten slotte onder meer de waterschapsverordening aan als 'omgevingsdocument'. In paragraaf 20.5.2 van de Omgevingswet worden regels gesteld over de beschikbaarstelling van omgevingsdocumenten. Bedoeling is dat omgevingsdocumenten worden opgenomen in het zogenaamde register omgevingsdocumenten (art. 20.28 Ow) en digitaal ontsloten worden via de landelijke voorziening (art. 20.23 Ow).

\section{Beoordelingsregels}

In dit kader dient ook iets te worden gezegd over de regels die gelden voor de beoordeling van vergunningaanvragen, zoals die nu zijn opgenomen in artikel 2.1 jo. artikel 6.13 en 6.21 van de Waterwet. Kernbepaling is artikel 5.3 van de Omgevingswet, dat bepaalt dat het zonder vergunning verboden is een activiteit te verrichten wanneer dat in de waterschapsverordening is bepaald. Bij de beoordeling van de vergunningaanvraag is een aantal bepalingen van paragraaf 5.1.3 van de Omgevingswet van belang. Artikel 5.18 van de Omgevingswet bepaalt dat bij algemene maatregel van bestuur regels worden gesteld over het verlenen of weigeren van een omgevingsvergunning voor een activiteit als bedoeld in artikel 5.1. Laatstgenoemd artikel bevat onder andere een opsomming van (voor zover dat een bij algemene maatregel van bestuur aangewezen geval betreft) vergunningplichtige 
activiteiten, waaronder lozings- en wateronttrekkingsactiviteiten en beperkingengebiedactiviteiten met betrekking tot waterstaatswerken en installaties in dergelijke werken. Artikel 5.24 van de Omgevingswet bepaalt dat voor een wateractiviteit de regels, als bedoeld in artikel 5.18 , gesteld worden met het oog op:

a. het voorkomen en waar nodig beperken van overstromingen, wateroverlast en waterschaarste;

b. het beschermen en verbeteren van de chemische en ecologische kwaliteit van watersystemen;

c. de vervulling van de op grond van deze wet aan watersystemen toegekende maatschappelijke functies;

d. het beschermen van de doelmatige werking van een zuiveringtechnisch werk, voor zover de regels een lozingsactiviteit op een oppervlaktewaterlichaam of een zuiveringtechnisch werk betreffen.

Dit zijn in vrijwel exact dezelfde bewoordingen de doelstellingen die momenteel in artikel 2.1 en 6.11 van de Waterwet zijn vastgelegd. In een (groot) aantal artikelen van het Bal zijn deze bepalingen nader geconcretiseerd. Artikel 5.24, onder c, van de Omgevingswet luidt net anders dan thans in artikel 2.1 van de Waterwet is verwoord ('(...) de op grond van deze wet aan watersystemen toegekende (...)'), maar via de Invoeringswet Omgevingswet zal de redactie van dit onderdeel weer volledig aan gaan sluiten bij de tekst van artikel 2.1 van de Waterwet.

Artikel 5.30 van de Omgevingswet schrijft voor dat de omgevingsvergunning alleen kan worden verleend of geweigerd op de gronden die in de waterschapsverordening zijn bepaald. De artikelen 5.31 en 5.32 van de Omgevingswet verschaffen het waterschapsbestuur de mogelijkheid de vergunning te weigeren in het geval en onder de voorwaarden als bedoeld in artikel 3 van de Wet bevordering integriteitsbeoordelingen door het openbaar bestuur (Wet BIBOB), respectievelijk ingeval het verlenen van de vergunning zou leiden tot ernstige nadelige of mogelijk ernstige nadelige gevolgen voor de gezondheid. Mogelijk biedt laatstgenoemd criterium een grondslag voor het bevoegd gezag om bepaalde lozingen, bijvoorbeeld bij nieuwe, nog niet genormeerde stoffen, te verbieden. Wanneer voor het verlenen van de omgevingsvergunning op grond van artikel 16.16 van de Omgevingswet de instemming van een ander bestuursorgaan nodig is, moet de vergunning op grond van artikel 5.33 van de Omgevingswet worden geweigerd als die instemming onthouden is. Artikel 5.34 van de Omgevingswet bevat bepalingen over de voorschriften die aan een omgevingsvergunning verbonden moeten 
worden. Ook hier biedt het Bal nadere concretisering. Ten slotte bevatten de artikelen 5.38 en 5.39 van de Omgevingswet bepalingen over de actualiseringsplicht respectievelijk de verplichting voor het bevoegd gezag om de vergunning te wijzigen dan wel in te trekken. Dit laatste moet plaatsvinden in gevallen of op gronden die bij algemene maatregel van bestuur of de waterschapsverordening zijn bepaald.

Als de huidige bepalingen van de model-Keur naast de Omgevingswet worden gelegd, dan lijkt allereerst te mogen worden geconcludeerd dat de waterschapsverordening in ieder geval niet dunner wordt dan de huidige keur. Alle onderwerpen die momenteel in deze model-Keur te vinden zijn, behoeven ook onder de Omgevingswet een plaats in de Handreiking waterschapsverordening. Daar komt bij dat het verplichte integrale karakter van deze verordening ertoe noopt ook de bestaande beschermingszones, in de zin van beperkingengebieden, algemene regels voor bepaalde activiteiten en een eventuele wegenkeur, in de waterschapsverordening op te nemen.

\section{(Kwalitatieve) lozingen}

Kwalitatieve lozingsactiviteiten verdienen hier bijzondere aandacht, doordat het met de Omgevingswet nadrukkelijk binnen het schootsveld van de waterschappen komt. In de bijlage bij art. 1.1 van de Omgevingswet worden de begrippen lozingsactiviteit op een oppervlaktewaterlichaam en lozingsactiviteit op een zuiveringtechnisch werk omschreven. De Omgevingswet hanteert een zogenaamd integraal lozingenbegrip, waarbij waterkwaliteit (stoffen en warmte) en waterkwantiteit (water) worden samengenomen.

Teneinde deze ingrijpende verandering te duiden, moet in herinnering worden geroepen dat er sinds 1970 met de inwerkingtreding van de Wvo landelijke regels bestaan over het lozen van afvalwater en afvalstoffen in oppervlaktewater om verontreiniging tegen te gaan en te voorkomen. De Wvo is eind 2009 opgegaan in de Waterwet, maar de landelijke regels zijn gebleven. De kern ligt in artikel 6.2 van de Waterwet, dat bepaalt dat het zonder vergunning verboden is te lozen (in de terminologie van de Waterwet 'het brengen van stoffen in een oppervlaktewaterlichaam of het brengen van water of stoffen op een zuiveringtechnisch werk'), tenzij er een vergunning of vrijstelling is verleend. In diverse algemene maatregelen van bestuur, in het bijzonder het Activiteitenbesluit milieubeheer, is ruimschoots invulling gegeven aan deze vrijstelling. Voorts is hierboven al naar voren gekomen dat de Omgevingswet een ander principe hanteert dan de Waterwet en lozingen alleen zijn verboden voor zover dat bij algemene maatregel van bestuur (zie art. 5.1, tweede lid, onder c, Ow) of in een waterschapsverordening is bepaald (zie art. $5.3 \mathrm{Ow}$ ). Zoals gezegd is in de memorie van toelichting bij de Omgevingswet uitgesproken dat in principe geen rijksregels zullen worden gesteld ten 
aanzien van waterstaatswerken die niet bij het Rijk in beheer zijn, en dat die regels door waterschappen in de waterschapsverordening moeten worden gesteld. Uit het Bal blijkt inderdaad dat er op rijksniveau beduidend minder geregeld wordt ten aanzien van lozingsactiviteiten. Dit geldt zowel voor de (directe) lozingen in oppervlaktewater en op zuiveringtechnische werken als voor de (indirecte) lozingen op de gemeentelijke riolering (het openbaar vuilwaterriool). Dat betekent conform de principes van de Omgevingswet meer ruimte voor de decentrale regelgever, in casu het waterschap (en gemeente en provincie voor indirecte lozingen), en mogelijkheden voor maatwerkregels naast of in afwijking van het Bal. Regels voor directe lozingen zijn straks te vinden in de waterschapsverordening en regels voor indirecte lozingen in het omgevingsplan van de gemeente. In beide gevallen is dit nieuw.

Dit nieuwe regime heeft het grote voordeel dat, waar de waterschappen in hun keur reeds lang regels stellen wat de waterkwantiteitsaspecten van lozingen betreft, straks kan worden uitgegaan van een integraal lozingenbegrip. Een lozingsactiviteit ziet zoals gezegd op het brengen van stoffen, water en warmte en ziet dus zowel op de waterkwaliteit (stoffen en warmte) als op de waterkwantiteit (water). Het waterschap kan deze activiteiten straks integraal benaderen en regionaal maatwerk leveren. Uiteraard waar nodig met inachtneming van eventuele instructieregels van de provincie of het Rijk op dit terrein (denk aan de verplichte instructieregels ter uitvoering van een aantal Europese richtlijnen en ten aanzien van zwemwater en stedelijk afvalwater op basis van art. $2.26,2.30$ en $2.31 \mathrm{Ow}$ ).

Het nieuwe regime van de Omgevingswet biedt daarmee kansen voor het waterschap, al zal de opstelling van een waterschapsverordening bepaald geen sinecure zijn, met name wat betreft de regulering van (kwalitatieve) lozingen in relatie tot de doelstelling van de kaderrichtlijn water in de waterschapsverordening. De Unie van Waterschappen is inmiddels ten behoeve van haar leden een project gestart dat moet resulteren in een Handreiking waterschapsverordening op basis van de Omgevingswet.

\subsection{Vaststellingsprocedure}

De waterschapsverordening wordt ingevolge art. 2.5 van de Omgevingswet vastgesteld door het algemeen bestuur (art. 56 jo. art. $78 \mathrm{Wschw}$ ). Artikel 2.8 van de Omgevingswet maakt het evenwel mogelijk dat de bevoegdheid tot het vaststellen van delen van de waterschapsverordening door het algemeen bestuur wordt gedelegeerd naar het dagelijks bestuur van het waterschap. ${ }^{25}$ Aldus ontstaat meer ruimte voor maatwerk. ${ }^{\mathbf{2 6}}$ Via delegatie kan het algemeen bestuur ervoor zorgen dat de uitvoering van het beleid, ook 
als dat een wijziging van de waterschapsverordening betreft, bij het dagelijks bestuur neergelegd wordt. Benadrukt zij dat deze regelgevende bevoegdheid van het algemeen bestuur vanuit het oogpunt van democratische legitimatie niet geheel kan worden overgedragen. Artikel 2.8 van de Omgevingswet spreekt daarom van 'delen van'. Een delegatiebesluit vormt een afzonderlijk besluit, dat geen deel uitmaakt van de verordening.

Op de voorbereiding van de waterschapsverordening is afdeling 3.4 van de Algemene wet bestuursrecht (Awb) van toepassing (art. 16.32 Ow). Verder zijn in afdeling 16.3 van de Omgevingswet enkele bepalingen opgenomen over de toepassing van de uniforme openbare voorbereidingsprocedure uit de Awb. De uniforme openbare voorbereidingsprocedure voorziet in een zienswijzemogelijkheid. Zienswijzen op het ontwerp kunnen door eenieder naar voren worden gebracht (art. 16.23, eerste lid, Ow).

Waterschapsverordeningen zijn in beginsel niet vatbaar voor beroep bij de bestuursrechter (art. 8:3, eerste lid, aanhef en onder a, Awb). Wanneer in een waterschapsverordening een beperkingengebied wordt aangewezen en daarvoor regels worden gesteld, dan is sprake van een appellabel besluit, waartegen volgens de hoofdregel van de Awb beroep in twee instanties openstaat. ${ }^{27}$

\subsection{Doorwerking van beleid en toezicht door hoger gezag}

Anders dan de Waterwet kent de Omgevingswet geen hoofdstuk of paragraaf over toezicht door hoger gezag. Wel bevat de Omgevingswet een afdeling over instructieregels en instructies (afdeling 2.5). In paragraaf 2.5.1 is de doorwerking van beleid door instructieregels geregeld. Paragraaf 2.5.2 geeft regels voor de doorwerking van beleid door instructies. In paragraaf 2.5.3 zijn bepalingen opgenomen over indeplaatstreding door provincie of Rijk en vernietiging van waterschapsbeslissingen door het Rijk. De instructieregels en instructies van provincie en Rijk richten zich daarbij zowel op gemeenten als op waterschappen, de bepalingen over indeplaatstreding en vernietiging in artikel 2.36 en 2.37 van de Omgevingswet hebben uitsluitend betrekking op waterschappen.

\subsubsection{Doorwerking van beleid door instructieregels}

Instructieregels zijn bedoeld voor situaties waarin de regel of het samenstel van regels gericht is tot verschillende overheidsorganen. ${ }^{\mathbf{2 8}}$ Er is sprake van een algemeenheid naar rechtssubject of naar gebied (of gebiedseenheid). Instructieregels lenen zich voor herhaalde toepassing: de norm moet steeds worden toegepast als de situatie zich voordoet die in de regeling is omschreven of is bedoeld. Deze instructieregels zijn te omschrijven als algemeen verbindende 
voorschriften die zich niet tot de burgers, maar tot bij die regels aangewezen bestuursorganen richten. Ze zien op de inhoud, toelichting of motivering van een besluit dat een bestuursorgaan neemt. Ook kunnen instructieregels worden gesteld over de uitoefening van een taak die in de Omgevingswet aan een bestuursorgaan is toegedeeld. De besluiten en taken waarover instructieregels kunnen worden gegeven, zijn in de Omgevingswet limitatief benoemd.

Artikel 2.22 van de Omgevingswet bevat de grondslag voor de provincies om, met inachtneming van de grenzen van het subsidiariteitsbeginsel (art. 2.3 Ow), algemene instructieregels aan gemeenten en waterschappen te stellen over de uitoefening van taken en bevoegdheden om te voldoen aan bij omgevingsverordening vastgestelde omgevingswaarden of voor het bereiken van andere doelstellingen voor de fysieke leefomgeving. De vindplaats voor deze instructieregels is dus de provinciale omgevingsverordening. De verwijzing naar het subsidiariteitsbeginsel impliceert dat instructieregels alleen mogelijk zijn als dat nodig is met het oog op een provinciaal belang en dat belang niet op een andere doelmatige of doeltreffende wijze door het gemeentebestuur of het waterschapsbestuur kan worden behartigd, of voor een doelmatige en doeltreffende uitvoering van de taken en bevoegdheden op grond van de Omgevingswet of de uitvoering van een internationaalrechtelijke verplichting. Deze omgevingsverordeningen moeten nog worden opgesteld, zodat het enigszins voorbarig is om op de mogelijke inhoud daarvan vooruit te lopen. Wel is het voorstelbaar dat de provincie gezien haar taak in die verordening met name aandacht zal besteden aan de relatie waterbeheer-ruimtelijke ordening.

Artikel 2.23 van de Omgevingswet bepaalt de inhoud van de provinciale instructieregels. In het eerste lid, onder a, is bepaald dat een instructieregel kan worden gesteld over de inhoud en motivering van een waterschapsverordening. Het derde lid kadert het stellen van instructieregels verder in. Het vierde lid bepaalt dat bij de instructieregels een termijn wordt gesteld waarbinnen uitvoering aan de regels moet zijn gegeven. Ten slotte bepaalt het vijfde lid dat bij de instructieregels moet worden aangegeven in welke gevallen en onder welke voorwaarden van de regels kan worden afgeweken als de toepassing van de regels niet toereikend is voor, of in de weg staat aan, het bereiken van de doelen van de Omgevingswet. Of provincies in de praktijk instructieregels zullen stellen over de waterschapsverordeningen, en zo ja welke, moet worden afgewacht. Vermeldenswaard is dat het IPO momenteel werkt aan een handreiking voor een omgevingsverordening.

De artikelen 2.24 en 2.25 van de Omgevingswet bevatten overeenkomstige bepalingen voor de instructieregels van het Rijk, die 
zich uiteraard niet alleen tot gemeenten en waterschappen, maar ook tot provincies kunnen richten. Artikel 2.25, eerste lid, onder a, van de Omgevingswet geeft de mogelijkheid om instructieregels te stellen over de inhoud en motivering van de waterschapsverordening. Een concreet voorbeeld van een instructieregel van het Rijk vormt artikel 6.1 van het Bkl. Dit artikel verplicht waterschappen ertoe om bij het stellen van regels over lozingsactiviteiten in de waterschapsverordening de eisen vanuit de kaderrichtlijn water in acht te nemen. Vanwege het uitgangspunt 'decentraal, tenzij' is de invulling hiervan overgelaten aan het decentraal bestuur.

Waterschappen kunnen ervoor kiezen in hun waterschapsverordening algemene regels te stellen of vergunningplichten in te stellen en/of maatwerkregels te stellen voor bepaalde activiteiten. Verzekerd moet zijn dat voldaan wordt aan de eisen vanuit de kaderrichtlijn water.

Artikel 2.32 van de Omgevingswet bevat een algemene ontheffingsmogelijkheid van de instructieregels van de provincie en het Rijk. Die regeling is overigens facultatief. Bij de instructieregels kan door de provincie en het Rijk worden bepaald dat op verzoek van een bestuursorgaan van een gemeente of waterschap (en bij instructieregels van het Rijk: of provincie) ontheffing van die regel kan worden verleend. Het vierde lid van artikel 2.32 van de Omgevingswet bepaalt dat een ontheffing alleen wordt verleend als de uitoefening van de taak of bevoegdheid waarvoor ontheffing wordt gevraagd 'onevenredig wordt belemmerd in verhouding tot het belang dat wordt gediend met de regel waarvan ontheffing is gevraagd'. De wet stelt dus zware eisen aan het kunnen verlenen van een dergelijke ontheffing. Aan die ontheffing kunnen op grond van het vijfde lid voorschriften worden verbonden. Tevens kan worden bepaald dat de ontheffing geldt voor een daarbij gestelde termijn (art. 2.32, zesde lid, Ow).

\subsubsection{Doorwerking van beleid door instructies}

Naast de bevoegdheid tot het stellen van instructieregels bevat de Omgevingswet een bevoegdheid voor de provincies en het Rijk tot het geven van een instructie. Deze instructie - te vergelijken met de 'aanwijzing' uit hoofdstuk 3 van de Waterwet - is bedoeld voor de proactieve coördinatie van de overheidszorg op die onderwerpen waar sprake is van een gedeelde verantwoordelijkheid of nauw verbonden verantwoordelijkheden, voor de verwezenlijking van provinciale of nationale belangen en voor een proactieve sturing of beleidsdoorwerking. ${ }^{29}$ De instructiebevoegdheid is aangewezen als het stellen van instructieregels wegens het beperkte aantal geadresseerden of de gewenste snelheid van uitvoering minder voor de hand liggend is. Waar instructieregels zich richten tot een aantal - en niet zelden alle - gemeenten en waterschappen, richt een instructie zich tot één of een beperkt aantal gemeenten of waterschappen. Een instructie is daarmee een besluit dat niet van algemene strekking is. Het is dus een 
beschikking als bedoeld in artikel 1:3, tweede lid, van de Awb.

Een instructie kan een opdracht bevatten tot het nemen, het niet nemen of het op een voorgeschreven wijze nemen van een besluit, maar ook een feitelijk handelen ter uitvoering van een taak of bevoegdheid in de vorm van een doen of nalaten. Als voorbeeld van een instructie door het Rijk wordt de opdracht voor één of een beperkt aantal provincies of gemeenten genoemd om voor de realisatie van een waterbergingsgebied een specifieke functieaanduiding of beperkende gebruiksbepalingen in de omgevingsverordening respectievelijk het omgevingsplan op te nemen.

Het is daarbij nadrukkelijk de bedoeling van de wetgever om te sturen op een terughoudend gebruik van de onderhavige bevoegdheden. Net als op het stellen van instructieregels is het subsidiariteitsbeginsel (art. $2.3 \mathrm{Ow}$ ) van toepassing op het geven van instructies. Ook geldt dat de besluiten en taken waarover instructies kunnen worden gegeven limitatief zijn benoemd. Naar het oordeel van de regering hoeft voor een vrijpostig en al te ruimhartig gebruik van deze bevoegdheden dan ook niet te worden gevreesd..$^{\mathbf{3 0}}$ Overigens heeft ook de toepassing door provincies en Rijk van de thans in de Waterwet opgenomen bevoegdheid tot het geven van een aanwijzing tot dusver uitermate terughoudend plaatsgevonden.

Artikel 2.33, eerste lid, van de Omgevingswet bevat de grondslag voor provinciale instructies. Gedeputeerde staten kunnen met inachtneming van het subsidiariteitsbeginsel het waterschapsbestuur waarvan het beheergebied geheel of grotendeels in de betrokken provincie is gelegen een instructie geven over de uitoefening van een taak of bevoegdheid. Een dergelijke instructie kan op grond van het tweede lid alleen worden gegeven aan het waterschapsbestuur als dat nodig is voor een samenhangend en doelmatig regionaal waterbeheer, en aan het dagelijks bestuur van een waterschap over een projectbesluit als bedoeld in artikel 5.44 of 5.46, tweede lid, van de Omgevingswet als dat nodig is met het oog op een evenwichtige toedeling van functies aan locaties. Van belang is dat het vierde lid bepaalt dat een instructie niet gegeven kan worden als toepassing kan worden gegeven aan de vernietigingsmogelijkheden van de Waterschapswet. Artikel 156 van de Waterschapswet bepaalt dat een besluit dan wel een niet-schriftelijke beslissing gericht op enig rechtsgevolg van een waterschapsbestuur door gedeputeerde staten kan worden vernietigd. ${ }^{\mathbf{3 1}}$

Artikel 2.34 van de Omgevingswet bevat een overeenkomstige bevoegdheid voor het Rijk, zij het dat deze een breder toepassingsbereik heeft, aangezien instructies van het Rijk zich ook tot de provincie kunnen richten. Als uitzonderingsgrond voor het geven van een instructie wordt in het vijfde lid ook de naleving van de Wet 
Naleving Europese regelgeving publieke entiteiten genoemd. Deze wet kent een eigen regime, dat dus boven dat van de Omgevingswet gaat. Voorts bevat artikel 19.16 van de Omgevingswet een specifieke regeling ingeval het waterschapsbestuur niet of niet voldoende optreedt bij gevaar voor waterstaatswerken (dit 'gevaar' kan niet alleen het doorbreken van een dijk of het afbranden van een gemaal betreffen, maar ook de verontreiniging van het oppervlaktewater door bijvoorbeeld een aanvaring). In die situatie kunnen gedeputeerde staten en in spoedeisende gevallen de commissaris van de Koning een instructie aan het waterschapsbestuur geven. Ingeval gedeputeerde staten of de commissaris van de Koning naar zijn oordeel ten onrechte niet of onvoldoende gebruik maken van deze bevoegdheid, kan de minister aan het waterschapsbestuur een instructie geven.

Het hiervoor reeds aangestipte meer individuele en enkelvoudige karakter van een instructie ten opzichte van de meer algemene en doorlopende strekking van instructieregels komt nog eens treffend naar voren in artikel 2.35 van de Omgevingswet. Dit artikel bepaalt dat een instructie niet gegeven kan worden als deze bedoeld is voor herhaalde uitvoering door meerdere bestuursorganen. In een dergelijke situatie moet dus voor instructieregels worden gekozen. Voorts bepaalt artikel 2.35, tweede lid, van de Omgevingswet dat als een instructie wordt gegeven met het oog op een nationaal of provinciaal belang dat niet op een doelmatige en doeltreffende wijze door het provinciebestuur respectievelijk gemeentebestuur kan worden behartigd, die instructie alleen kan worden gegeven als dat belang is aangegeven in een door het bestuursorgaan van het Rijk of de provincie openbaar gemaakt document. Deze bepaling beoogt een rem te zetten op al te lichtvaardig gegeven instructies.

\subsubsection{Toezicht door hoger gezag}

Artikel 2.36 van de Omgevingswet regelt specifiek ten opzichte van het waterschapsbestuur de bevoegdheid tot indeplaatstreding door gedeputeerde staten of de minister. Als het waterschapsbestuur niet binnen de daarvoor gestelde termijn uitvoering geeft aan de instructie op grond van artikel 2.33 van de Omgevingswet, dan kunnen gedeputeerde staten of de minister namens dat bestuur en ten laste van dat waterschap voorzien in het gevorderde.

Via de Invoeringswet Omgevingswet wordt deze bevoegdheid uitgebreid met de situatie dat het waterschap een bij of krachtens afdeling 18.3 (Kwaliteitsbevordering en afstemming uitvoering en handhaving) van de Omgevingswet gevorderde beslissing niet of niet naar behoren neemt dan wel een bij of krachtens die afdeling gevorderde handeling niet of niet naar behoren verricht. De provinciale bevoegdheid is daarbij beperkt tot beslissingen en handelingen krachtens afdeling 18.3 van de Omgevingswet. De 
bevoegdheid van het Rijk strekt zich uit tot hoofdstuk 18 (Handhaving en uitvoering) van de Omgevingswet in zijn geheel. Deze verreikende bevoegdheid tot indeplaatstreding van de provincie en het Rijk is afkomstig uit de Waterwet (art. 3.12 en 3.13). Uiteraard zal tot indeplaatsstelling niet lichtvaardig worden besloten en vindt tevoren overleg plaats met het waterschapsbestuur.

Nieuw is dat het Rijk in artikel 2.37 van de Omgevingswet de bevoegdheid wordt toegekend om besluiten of niet-schriftelijke beslissingen gericht op enig rechtsgevolg van het waterschapsbestuur, genomen in strijd met een instructieregel of instructie, bij koninklijk besluit te vernietigen. Via de Invoeringswet Omgevingswet wordt daar het bepaalde bij of krachtens hoofdstuk 18 aan toegevoegd. Deze nieuwe bevoegdheid vormt als het ware het interbestuurlijke sluitstuk op de onderhavige regeling. Zou het Rijk deze bevoegdheid ontberen, dan zou het waterschapsbestuur de instructieregels en instructies van het Rijk en het bepaalde bij of krachtens hoofdstuk 18 in beginsel immers zonder sanctie kunnen negeren. De vernietigingsbevoegdheid van het Rijk beperkt zich dan ook nadrukkelijk tot dergelijke handelingen van het waterschap.

Overigens wordt erop gewezen dat wanneer sprake is van een met een instructie strijdig genomen besluit voor het Rijk of de provincie ook de weg van beroep openstaat. Dat naast de generieke interbestuurlijke toezichtinstrumenten ook de weg van beroep openstaat, leidt niet tot een dubbeling van procedures of een mogelijkheid tot herkansing. ${ }^{\mathbf{2}}$ Aan een dubbeling van procedures staat artikel 10:38, tweede lid, van de Awb namelijk in de weg. Een genomen besluit kan niet worden vernietigd als het nog vatbaar is voor bezwaar of beroep. Herkansing wordt uitgesloten in artikel 10:37 van de Awb. In dit artikel is geregeld dat wanneer een rechter over een besluit een uitspraak heeft gedaan, dat besluit niet kan worden vernietigd op gronden die in strijd zijn met de uitspraak van de rechter.

\subsection{Betekenis jurisprudentie}

De waterschapsverordening op grond van de Omgevingswet is de opvolger van de huidige waterschapskeur. In zoverre is het nuttig om kort stil te staan bij de jurisprudentie die zich de afgelopen jaren ten aanzien van deze keur ontwikkeld heeft. ${ }^{33}$ Voor een belangrijk deel behoudt deze jurisprudentie onder de Omgevingswet haar betekenis.

Een cruciale bepaling in dit verband, die in het verleden tot enkele rechterlijke uitspraken heeft geleid, is artikel 59 van de Waterschapswet. ${ }^{\mathbf{3 4}}$ Het eerste lid van dit artikel bepaalt dat ten aanzien van onderwerpen waarin door een wet, een algemene maatregel van bestuur of een provinciale verordening is voorzien, het waterschapsbestuur bevoegd is tot het maken van verordeningen voor 
zover deze verordeningen niet met die hogere regelingen in strijd zijn. Op grond van het tweede lid houden bepalingen van verordeningen waarvan, nadat deze zijn vastgesteld, wordt voorzien door een wet, een algemene maatregel van bestuur of een provinciale verordening, van rechtswege op te gelden. De vroegere Keurenwet kende een overeenkomstige bepaling. Ook de Provinciewet en de Gemeentewet kennen in de artikelen 119 respectievelijk 112 vergelijkbare bepalingen, die in onze gedecentraliseerde eenheidsstaat onmisbaar moeten worden geacht. De essentie van de bepaling is in de eerste plaats dat het waterschapsbestuur, ook al is het betreffende onderwerp geregeld in een hogere regeling, bevoegd is tot nadere regeling, mits het de bepalingen van die hogere regeling in acht neemt en daarmee niet in strijd komt. In de tweede plaats betekent het dat als een onderwerp dat geregeld is in een verordening van het waterschap, die reeds is vastgesteld, op een later tijdstip wordt geregeld in een hogere regeling, de betreffende bepalingen uit de waterschapsverordening van rechtswege ophouden te gelden. In dit verband wordt nog benadrukt dat het om 'hogere' regelingen moet gaan, dus regelingen van de provincie of het Rijk. Gemeenten en waterschappen staan hiërarchisch op hetzelfde niveau en hun verordeningen zijn van gelijke rangorde. Tussen dit tweetal overheidslichamen is geen sprake van hogere en lagere regelingen. Een gemeentelijke verordening gaat dus niet boven een waterschapsverordening.

Met de Omgevingswet krijgt deze bepaling als het ware een extra dimensie. De waterschapsverordening heeft daarin immers een sterke, eigen positie gekregen door de nadruk die de wetgever heeft willen leggen op decentrale regelgeving. Ook voorziet de Omgevingswet, anders dan de Waterschapswet, nadrukkelijk in de mogelijkheid om in de waterschapsverordening via maatwerkvoorschriften en maatwerkregels af te wijken van hogere regelingen, zoals de algemene instructieregels van het Rijk en de provinciale omgevingsverordening (zie ook par. 10.2.3).

Zoals gezegd heeft de rechter zich in het verleden en voor een deel nog op basis van de vroegere Keurenwet enkele malen uitgesproken over artikel 59 van de Waterschapswet. Aangezien die uitspraken ook onder de Omgevingswet hun gelding behouden, worden deze hierna kort toegelicht.

De eerste uitspraak leert dat een lagere en hogere regeling weliswaar hetzelfde onderwerp kunnen regelen, maar dat zij naast elkaar kunnen bestaan wanneer de betrokken bepalingen een verschillend belang beogen te beschermen. In casu gold dit naar het oordeel van de Hoge Raad voor het in de Algemene Keur van het Hoogheemraadschap van Delfland opgenomen verbod tot het met woonschepen innemen van een ligplaats en het daaromtrent bepaalde in de Wet op de woonwagens en woonschepen. ${ }^{35}$ Aangezien de keur de bescherming 
van waterstaatswerken ten doel heeft en genoemde wet het huisvestingsbeleid regelt, konden beide regelingen volgens de Hoge Raad naast elkaar bestaan.

Een tweede uitspraak betreft de relatie tussen de reeds bestaande keur van het Hoogheemraadschap van de Alblasserwaard en de Vijfheerenlanden en een later reglement van de provincie ZuidHolland, die beide hetzelfde onderwerp regelen, te weten de instandhouding van de binnenwaterkeringen in voortdurende waterkerende toestand. In dit geval was er dus geen sprake van een verschillend belang. De Afdeling oordeelde dan ook dat bij de betreffende vergunningaanvraag de bepalingen uit het provinciaal reglement hadden moeten worden toegepast en dat geen toepassing gegeven had kunnen worden aan de keur van het waterschap. ${ }^{\mathbf{3 6}}$

Een derde uitspraak betreft de samenloop van een waterschapsverordening en een gemeentelijke verordening, die zoals gezegd van gelijke rangorde zijn. Het is voorstelbaar dat bepalingen in een keur niet overeenkomen met de bepalingen in een gemeentelijk bestemmingsplan. Daarin kan bijvoorbeeld zijn bepaald dat voor het uitvoeren van een werk, geen bouwwerk zijnde, of werkzaamheden een omgevingsvergunning (voorheen aanlegvergunning) vereist is. Het bestemmingsplan op grond van de Wet ruimtelijke ordening ziet op een goede ruimtelijke ordening waartoe onder meer regels kunnen worden gesteld inzake het dempen of graven van sloten in verband met de bescherming van landschappelijke of archeologische waarden. Vanuit de zorg voor het watersysteem kan ook het waterschap echter in de keur regels stellen over dergelijke activiteiten. Deze regels kunnen afwijken van die uit het bestemmingsplan. Beide regels kunnen naast elkaar bestaan. ${ }^{\mathbf{3 7}}$

Dat deze jurisprudentie qua omvang bescheiden is en vaak al dateert van vóór de inwerkingtreding van de Waterschapswet illustreert dat de verschillende bestuurslichamen elkaars taken en bevoegdheden doorgaans goed weten te respecteren en - om een toepasselijke term te hanteren - niet in elkaars vaarwater komen. Dit laatste zal naar verwachting onder de Omgevingswet niet anders zijn, gelet op het integrale karakter van de wet en de nadruk die de wetgever heeft willen leggen op het stellen van regels op het laagste overheidsniveau en het in artikel 2.3 van de Omgevingswet vastgelegde subsidiariteitsbeginsel.

\subsection{Overgangsrecht}

Uiteraard moet volstrekt helder zijn wanneer de verplichting ingaat voor de waterschappen om een waterschapsverordening te hebben. Ook moet worden voorzien in een soepele overgang van het regime van de keur onder de Waterschapswet naar dat van de 
waterschapsverordening onder de Omgevingswet. Dit vindt plaats via de Invoeringswet Omgevingswet en het Invoeringsbesluit Omgevingswet.

In dit kader is artikel 11.55 van de Invoeringswet Omgevingswet van belang. Het eerste lid van dit artikel bepaalt dat het tijdstip waarop het vaststellen van een waterschapsverordening verplicht is bij koninklijk besluit zal worden bepaald. Dit tijdstip, dat na overleg met de Unie van Waterschappen zal worden bepaald, ligt naar verwachting op twee jaar na het moment van inwerkingtreding van de Omgevingswet. In overgangsrechtelijke termen is - zo wordt opgemerkt in de memorie van toelichting bij de Invoeringswet Omgevingswet - gekozen voor 'uitgestelde werking'.$^{\mathbf{3 8}}$ Als redenen hiervoor wordt enerzijds gewezen op de verplichting voor de waterschappen om op basis van de plancyclus uit het Europese recht ook nieuwe waterbeheerprogramma's vast te stellen, waarop de overgangstermijn van de waterschapsverordening kan aansluiten, en anderzijds wordt erop gewezen dat een provinciale omgevingsverordening instructieregels voor waterschapsverordeningen kan bevatten. Aangezien de algemene besturen van de waterschappen daar bij het vaststellen van hun verordeningen rekening mee moeten houden, kunnen de waterschapsverordeningen dus niet worden vastgesteld op het moment van inwerkingtreding van de Omgevingswet. Ook de provincies zal immers voldoende tijd moeten worden gegund om de omgevingsverordening vast te stellen. Het tijdstip waarop uiterlijk moet worden voldaan aan de verplichting tot het vaststellen van een waterschapsverordening wordt in het Invoeringsbesluit Omgevingswet bepaald.

Het tweede lid van artikel 11.55 van de Invoeringswet Omgevingswet bepaalt dat een van kracht zijnde keur als bedoeld in de Waterschapswet blijft gelden totdat de waterschapsverordening van kracht is. Deze gebruikelijke overgangsbepaling is noodzakelijk om een rechtsvacuüm te voorkomen. Het derde lid voegt hieraan toe dat wanneer een keur (nog) niet van kracht is, het oude recht daarop van toepassing blijft indien een ontwerp daarvan vóór de inwerkingtreding van artikel 2.5 van de Omgevingswet ter inzage is gelegd. Wanneer een waterschap vóór de inwerkingtreding van de Omgevingswet een herziening van de keur in procedure heeft gebracht, blijft het oude recht daarop dus van toepassing, ook al is die nieuwe keur nog niet van kracht. Deze bepaling dient ertoe om een zo soepel mogelijke overgang van het oude op het nieuwe regime te realiseren.

Het vierde lid bepaalt dat de vaststelling of wijziging van een beschermingszone als bedoeld in de Waterwet die onherroepelijk is, blijft gelden tot voor deze waterstaatswerken in de waterschapsverordening een beperkingengebied als bedoeld in de Omgevingswet is opgenomen. Zoals bekend kent de Omgevingswet 
niet het systeem van beschermingszones uit de Waterwet (zie art. 1.1, eerste lid), maar van beperkingengebieden (zie de bijlage bij art. 1.1). Het betreft hier een louter terminologische wijziging, een materiële wijziging is niet beoogd. Met de onderhavige overgangsbepaling wil de wetgever bewerkstelligen dat bestaande beschermingszones, die soms zoals gezegd in de legger zijn opgenomen, hun gelding behouden totdat deze in de waterschapsverordening zijn getransformeerd in beperkingengebieden als bedoeld in de Omgevingswet.

In dit kader wordt ten slotte gewezen op artikel 22.13 van de Invoeringswet Omgevingswet. Het eerste lid van deze bepaling houdt in dat bij algemene maatregel van bestuur kan worden bepaald dat regels die vóór de inwerkingtreding van de Omgevingswet of krachtens een andere wet waren gesteld of daaraan gelijkwaardige regels, onderdeel uitmaken van de omgevingsverordening en de waterschapsverordening. Het tweede lid bepaalt dat bij een besluit tot vaststelling of wijziging van deze verordeningen die regels kunnen worden gewijzigd. Op het eerste gezicht is wellicht niet direct duidelijk aan wat voor soort regels hierbij moet worden gedacht. Gedacht kan worden aan bepaalde lozingsactiviteiten in regionale wateren, die niet langer bij algemene maatregel van bestuur, maar voortaan in de waterschapsverordening (moeten) worden geregeld. ${ }^{39}$ Aangezien de Omgevingswet uitgaat van het principe 'decentraal, tenzij' worden veel regels niet langer op rijksniveau, maar op decentraal niveau gesteld. Verwacht wordt dat de decentrale overheden die regels op het moment van inwerkingtreding van de Omgevingswet nog niet volledig zullen hebben vastgesteld. Om die reden voorziet de Omgevingswet in een soepel overgangsregime, waarin de rijksregels hun gelding tot dat moment nog behouden.

\section{Noten}

1 Zie uitgebreider G.P. van de Ven (red.), Leefbaar Laagland: geschiedenis van de waterbeheersing en landaanwinning in Nederland, Utrecht: Matrijs 2003 en H.J.M. Havekes, Functioneel decentraal waterbestuur: borging, bescherming en beweging. De institutionele omwenteling van het waterschap in de afgelopen vijftig jaar (diss. Utrecht), Den Haag: Sdu Uitgevers 2009.

2 Zie uitvoeriger over de consequenties van het opgaan van de Waterwet in de Omgevingswet F.A.G. Groothuijse, Integratie van de Waterwet in de Omgevingswet, $M$ en $R$ 2012/81, M.J. Kraak \& W.J. Wensink, Waterwet in Omgevingswet, Het Waterschap 2013, nr. 5, p. 26-27, H.J.M. Havekes \& W.J. Wensink, Omgevingswet waterproof?, TO 2013, nr. 2, p. 68-81 en M.J. Kraak \& W.J. Wensink, De Omgevingswet: waterbestendig of waterdoorlatend?, TO 2016, nr. 6, p. 167-177. 
3 Kamerstukken II 2014/15, 33 962, nr. 3, p. 52 e.v.

4 Zie uitgebreider H.J.M. Havekes \& W.J. Wensink (red.), De Waterschapswet. Een artikelsgewijs commentaar, Deventer: Wolters Kluwer 2015, p. 176-180 en 203 e.v.

5 De MvT spreekt hier van 'vrij medebewind', Kamerstukken II 2014/15, 33 962, nr. 3, p. 44.

6 Kamerstukken II 2014/15, 33 962, nr. 3, p. 441.

7 Kamerstukken II 2014/15, 33 962, nr. 3, p. 135.

8 Zie uitgebreider J.C. Ozinga \& W.J. Wensink, Lozingen onder de Waterwet en de Wabo, $M$ en $R$ 2011/1.

9 Kamerstukken II 2013/14, 33 962, nr. 3, p. 43-44.

10 Kamerstukken II 2013/14, 33 962, nr. 3, p. 75-77.

11 Kamerstukken II 2013/14, 33 962, nr. 3, p. 75-76.

12 Kamerstukken II 2013/14, 33 962, nr. 3, p. 76-77.

13 Kamerstukken II 2013/14, 33 962, nr. 3, p. 80-81.

14 Te raadplegen via: www.uvw.nl/publicatie/afsprakenkaderomgevingswet.

15 Zie A.A. Beekman, Het dijk- en waterschapsrecht in Nederland vóór 1795, Den Haag: Nijhoff 1907, p. 942-969, voor een uitvoerig overzicht van waterschapskeuren, dat teruggaat tot de tweede helft van de dertiende eeuw.

16 Kamerstukken II 2013/14, 33 962, nr. 3, p. 52 e.v.

17 Zie voor een uitvoerige toelichting op laatstgenoemde bepalingen Havekes \& Wensink 2015, p. 176-180 en 203-209.

18 Kamerstukken II 2013/14, 33 962, nr. 3, p. 93-94.

19 Zie uitgebreider par. 10.2.3.

20 Kamerstukken II 2013/14, 33 962, nr. 3, p. 87.

21 Te raadplegen via: www.uvw.nl/thema/wet-enregelgeving/modelkeur. Zie hierover W.J. Wensink, Het keurkwartet, Het Waterschap 2013, nr. 3, p. 26-27. 
22 Deze legger van onderhoudsplichtigen moet niet worden verward met de legger van artikel 5.1 van de Waterwet (art. 2.39 Ow), waarin omschreven is waaraan waterstaatswerken naar ligging, vorm, afmeting en constructie moeten voldoen.

23 Aangezien art. 2.1 van de Omgevingswet, anders dan art. 2.17 van de Omgevingswet, het begrip 'waterketenbeheer' niet expliciet noemt, lijkt dat buiten de reikwijdte van het begrip fysieke leefomgeving te vallen. Gezien de duidelijke formulering van art. 2.17 lijkt hier echter sprake van een omissie en kan de waterschapsverordening zich zo nodig uitstrekken tot het waterketenbeheer, voor zover dat berust bij waterschappen (het beheer van zuiveringtechnische werken).

24 Kamerstukken II 2013/14, 33 962, nr. 3, p. 481.

25 Via de Invoeringswet Omgevingswet wordt art. 83 van de Waterschapswet hierop aangepast.

26 Kamerstukken II 2013/14, 33 962, nr. 3, p. 403-404.

27 Kamerstukken II 2013/14, 33 962, nr. 3, p. 299.

28 Kamerstukken II 2013/14, 33 962, nr. 3, p. 104-108.

29 Kamerstukken II 2013/14, 33 962, nr. 3, p. 108-112.

3o Kamerstukken II 2013/14, 33 962, nr. 3, p. 102-104.

31 Zie voor een uitgebreide toelichting op dit artikel Havekes \& Wensink 2015, p. 471-477.

32 Kamerstukken II 2013/14, 33 962, nr. 3, p. 111-112.

33 Zie voor een rechterlijke toetsing van de keur, legger en keurkaart ABRvS 24 december 2013, Het Waterschap 2014, nr. 1/2, p. 30 m.nt. M.J. Kraak en A.R. Krijgsman.

34 Zie voor een toelichting op dit artikel Havekes \& Wensink 2015, p. 184-186.

35 HR 22 januari 1963, NJ 1963/121.

36 AGRvS 12 december 1990, $A B$ 1991/361 m.nt. J.J.I. Verburg. Zie ook AGRvS 23 november 1990, $A B$ 1991/324.

37 ABRvS 12 november 2008, $M$ en $R$ 2009/45 m.nt. F.A.G. Groothuijse. 
38 Zie uitgebreider MvT Invoeringswet Omgevingswet, par. 11.3.10.

39 MvT Invoeringswet Omgevingswet, p. 254.

(c) Boom juridisch 